TEME, г. XLI, бр. 1, јануар-март 2017, стр. 297-299

Приказ дела

DOI: $10.22190 /$ TEME1701297M

Примљено: 26. 02. 2017.

Одобрено за штампу: 27. 02. 2017.

\title{
HUMAN RESOURCE MANAGEMENT IN THE CONDITIONS OF GLOBALIZATION*
}

\author{
Sandra Milanović \\ University of Niš, Faculty of Economics, Niš, Serbia \\ sandramilanović89@yahoo.com
}

The key phenomenon that marked the end of the 20th century, as well as the begining of the 21 st century, without any doubt, is the process of globalization. This process iniciated tremendes changes in the whole world on many levels where economy is one of them. Due the process of globalization the whole world became the potential market for organization. Spreading the business over national borders, however, requires specific approach in managing human resources. Since the workforce is dispersed at different locations in the world and usually belongs to different cultural, educational, legal and political systems, traditional human resource management (HRM) requires some changes and often completely new activities. Therefore new concept, international human resource management (IHRM) has been emerged. Having in mind the importance of effectively managing the human resources on international business scene, Biljana Djordjevic, Ph.D., and Ivan Markovic, Ph.D., professors at the Faculty of Economics, University of Nis, in their monograph Human Resource Management in the Conditions of Globalization provide the answers on many important questions regarding the IHRM: why IHRM is important for competitiveness of organization that expand their business activities abroad, what is the content of IHRM, what are the specifics of IHRM in comparation to domestic HRM, which factors from international context influence those specifics, etc.

The monograph consists of three parts: Globalization as a phenomenon of the modern world (chapters one to three), International human resource management as a conceptual framework for human resource management in multinational companies (chapters four and five) and The content of international human resource management in multinational companies (chapters six to twelve).

In first chapter, The basic dimensions of globalization as a modern phenomenon (pp. 1-17) the authors presented the basic characteristics of the concept of globalization which are seen as the crucial factors for intensive development of the concept of IHRM. The authors started with the definition of the concept of

\footnotetext{
* Biljana Đorđević \& Ivan Marković (2016). Upravljanje ljudskim resursima u uslovima globalizacije, Niš: Ekonomski fakultet Univerziteta u Nišu; p. 277 [Human Resource Management in the Conditions of Globalization]
} 
globalization. Further it was given the analysis of processes that had led to the phenomena of globalization. The authors also analyzed the basic characteristics of global market and global products which are seen as the main categories around which the process of globalization is structured.

In the second chapter, The basic levers of the process of globalization (pp. 17-37), the authors analyzed crucial levers, such as: political lever, legal lever, scientific and technical progress, information technology, institutional lever and other levers.

The third chapter, Multinational and transnational companies as the key bearers of the process of globalization (pp. 37-80), the authors examined similarities and differences between multinational companies (MNCs) and transnational companies (TNCs). In this part of the monograph certain attention has been dedicated to determining the role and position of these companies in the process of globalization and their impact on international trade. At the end of this part the authors emphasized that the main source of sustainable competitive advantage of MNCs and TNCs are higly competent human resources supported by adequate system of IHRM.

In the fourth chapter, International human resource management - the basic dimensions (pp. 81-100), the authors dealt with the basic dimensions of the concept of IHRM. In this regard, firstly it was given an answer what IHRM realy means and what was the developmental process of this concept. The authors concluded that there is a consensus in the literature that IHRM covers three main areas, such as: multicultural management, comparative human resource management and international human resource management practices (p.88). Furher the authors gave an overview of the factors that influence the most the content of IHRM. As the most important the authors noted: socio-cultural factors, economical factors, legal and political factors and technological factors. In this part of the monograph special attention has been put on analyzing the basic approaches in IHRM. The authors noted that these approaches are: ethnocentric, polycentric, regiocentric and global approach. At the end of this part of the monograph the authors pointed out that the knowledge regarding IHRM is usefull in many areas and institutions, such as MNCs, domestic companies working with foreign MNCs, companies that employ people coming from other cultures, various government and non-government organizations as well as global organizations such as the World Bank, the United Nations and others.

In the fifth chapter, Culture as a factor of international human resource management (pp. 101-128), the authors pointed out that the culture is one of the most important factors that influence the content of IHRM. Therefore, they gave an overview of the most important dimensions of national culture identified by the referent authors in this field. They also analyzed the influence of national culture on the content of IHRM, respectively, on the process of recruitment, selection, training and development, performance assessment and rewarding of the employees. Finally, special attention was dedicated to the cultural intelligence as the ability of an individual to successfully adapts to different cultural context.

The sixth chapter, Human resource planning in multinational companies (pp.129-142), places an emphasis on stages in the process of human resources planning. The authors state that this process starts with the collection and analying of the data obtained from internal and external environment. After that prediction of supply and demand for human resources is carrying out. The next stage is determining 
whether there is a balance or imbalance among them. At the end of this process, plans are implementing and their implementation occasionally is controling.

In the seventh chapter, Saffing policy in the multinational companies (pp.143165), the authors stressed that international staffing policy involves two key activities: recruitment and selection of the candidates (p.143). The authors pointed out that finding candidates for filling the job possition in the MNC may be conducted internally or at the external labor market. In order to choose appropriate candidates the authors noted the certain criterions must be applied.

The eighth chapter, Training of the employees in the multinational companies (pp. 165-172) explores challenges in organizing training activities in MNCs. The authors pointed out that training of the employees in $M N C$ is very important for their competitive position (p.166).

In the ninth chapter, Long-term international assignment of the employees basic characteristics and key challenges (pp. 172-220), the authors examined the basic characteristics of the long-term international assignment of the employees, motives for sending the expatriates abroad, characteristics that one expatriate should possesses, phases of long-term international assignment as well the basic characteristics of other forms of the employees` international assignments.

In the tenth chapter, Performance assessment of the employees in the multinational companies (pp. 220-234), the authors claim that there are three different approaches for conducting this process: "exporting" approach, adaptive approach and integrative approach ( $\mathrm{p} .221)$. The authors state that choosing certain approach is usually based on the decision if the MNC will respect the influence of the contextual factors and preferences of the local employees.

The eleventh chapter, Rewarding system in the multinational companies (pp. 234-250), deals with different policies that can be used for rewarding the employees in MNCs. The authors also state that rewarding system in MNCs could be seen as composition of two parts: rewarding system for expatriates and rewarding system for other employees.

In the last chapter, The role of multinational companies in the management of labor relations in subsidiaries (pp. 250-261), is highlighted the role of MNC in the process of managing labor relations. The authors stressed that the major challenge in this filed is to determine the degree in which MNC should be involved in this process and what approach to implement.

The monograph Human Resource Management in the Conditions of Globalization belongs to rare publications in this field on the territory of the Republic of Serbia. Therefore its significance lay in the fact that it represents a rare comprehensive overview of the basic features of the IHRM. The quality of the monograph is also the understandable style of writing. Therefore the readers can easily and gradually introduce with basics characteristics of the concept of IHRM and the process of globalization which initiated the dinamic development of IHRM. The monograph IHRM can be usefull material for anyone who want to become more familiar with the content of IHRM and its basic characteristics. 